\title{
Evaluation of the diabetes in pregnancy study group of India criteria and Carpenter-Coustan criteria in the diagnosis of gestational diabetes mellitus
}

\section{Gestasyonel diabetes mellitus tanisinda Hindistan kriterleri ve Carpenter-Coustan kriterleri ile gebelik çalışma grubunda diyabetin değerlendirilmesi}

\author{
(1) Shazia Khan1, (1) Himadri Bal2, (1) Inam Danish Khan³, (1) Debashish Paul4 \\ ${ }^{1}$ INHS Kalyani Hospital, Clinic of Obstetrics and Gynecology, Visakhapatnam, India \\ ${ }^{2}$ Dr. DY. Patil Medical College Hospital and Research Centre, Clinic of Obstetrics and Gynecology, Pune, India \\ 3 Army College of Medical Sciences and Base Hospital, Clinic of Microbiology, New Delhi, India \\ ${ }_{4}^{4}$ Armed Forces Medical College, Clinic of Obstetrics and Gynecology, Pune, India
}

\begin{abstract}
Objective: Gestational diabetes mellitus (GDM) is defined as any degree of glucose intolerance that is diagnosed for the first time during pregnancy. This prospective study was undertaken to validate the single-step non-fasting 75 gm Diabetes in Pregnancy Study Group of India (DIPSI) criteria of GDM in Indian patients in comparison with the two-step fasting $100 \mathrm{gm}$ glucose challenge through the Carpenter Coustan criteria (CCC). Materials and Methods: Two hundred patients underwent comparative testing using the DIPSI criteria and CCC. Plasma venous blood glucose levels were estimated using the hexokinase method; values $\geq 140 \mathrm{mg} / \mathrm{dL}$ at 2 hours were considered positive according to the DIPSI criteria. Any two values from $\geq 95 \mathrm{mg} / \mathrm{dL}$ for fasting, $\geq 180 \mathrm{mg} / \mathrm{dL}$ at 1 hour, $\geq 155 \mathrm{mg} / \mathrm{dL}$ at 2 hours, and $\geq 140 \mathrm{mg} / \mathrm{dL}$ at 3 hours were considered positive with the CCC. Results: The mean age and body mass index were $24.26 \pm 3.75$ years and $20.7 \pm 3.07 \mathrm{~kg} / \mathrm{m}^{2}$. The sensitivity, specificity, and positive and negative predictive values of the DIPSI guidelines were found as 100\%, 97.14\%, $83.87 \%$, and 100\%, respectively. The positive and negative likelihood ratios were 35.8 and zero. Diagnostic accuracy was found as $97.56 \%$.

Conclusion: DIPSI having high sensitivity, specificity, negative predictive value and diagnostic accuracy. DIPSI offers simplicity, feasibility, convenience, and repeatability while economizing universal screening and diagnosis of GDM on a mass-scale. The DIPSI procedure has the potential to be applied to the entire obstetric population, in the implementation of public health programs to diagnose GDM in the community, thus reaching the needs of the developing world.
\end{abstract}

Keywords: Gestational diabetes mellitus, Diabetes in Pregnancy Study Group of India criteria, Carpenter Coustan criteria, pregnancy, glucose tolerance test

$\ddot{\mathrm{O} z}$

Giriş: Gestasyonel diabetes mellitus (GDM) gebelik sırasında ilk kez teşhis edilen herhangi bir glukoz intolerans derecesi olarak tanımlanır. Bu prospektif çalışma Hintli hastalarda; tek aşamalı, tok, 75 g glukoz yüklemesine dayanan Hindistan'da Hamilelikte Diyabet Çalışması Grubu (DIPSI) kriterlerinin, iki aşamalı, aç, 100 g glukoz yüklemesine dayanan Carpenter Coustan kriteri (CCK) kriterleri ile karşılaştırılarak doğrulanması için yapılmıştır.

Gereç ve Yöntemler: İki yüz hastaya DIPSI kriterleri ve CCK kullanılarak karşılaştırmalı test uygulandı. Plazma venöz kan glukoz düzeyleri hekzokinaz yöntemi kullanılarak hesaplandı; DIPSI kriterlerine göre 2 saatte $140 \mathrm{mg} / \mathrm{dL}$ 'nin üstündeki değerler pozitif olarak değerlendirildi. Açlık için $\geq 95$ mg/dL, 1 saatte $\geq 180 \mathrm{mg} / \mathrm{dL}, 2$ saatte $\geq 155 \mathrm{mg} / \mathrm{dL}$ ve 3 saatte $140 \mathrm{mg} / \mathrm{dL}$ olmak üzere herhangi iki değer CCK ile pozitif olarak değerlendirildi.

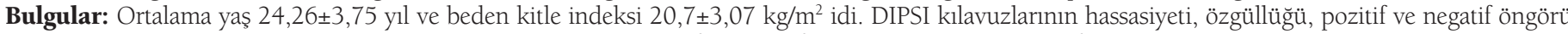
değerleri sirasiyla \%100, \%97,14, \%83,87 ve \%100 bulundu. Pozitif ve negatif öngörü oranları 35,8 ve sifır idi. Tanı doğruluğu \%97,56 olarak bulundu.

Sonuç: DIPSI; yüksek hassasiyete, özgüllüğe, negatif öngörü değerine ve tanısal doğruluğa sahiptir. Kitlesel ölçekte, GDM tanısını ve evrensel taramayı hızlandırırken basitlik, fizibilite, rahatlık ve tekrarlanabilirlik sunar. DIPSI prosedürü; toplumda GDM'yi teşhis etmek için halk sağlı̆̆ı programlarına, tüm obstetrik popülasyona uygulanabilecek potansiyele sahip olup, böylece gelişmekte olan dünyanın ihtiyaçlarına ulaşmaktadır.

Anahtar Kelimeler: Gestasyonel diabetes mellitus, Hindistan'da Hamilelikte Diyabet Çalışması Grubu kriterleri, Carpenter Coustan kriterleri, gebelik, glukoz tolerans testi

Address for Correspondence/Yazışma Adresi: Inam Danish Khan, MD,

Army College of Medical Sciences and Base Hospital, Clinic of Microbiology, New Delhi, India

Phone: +918076324060 E-mail: titan_afmc@yahoo.com ORCID ID: orcid.org/0000-0002-9824-8711

Received/Geliș Tarihi: 15.01.2018 Accepted/Kabul Tarihi: 18.03.2018

${ }^{\circledR}$ Copyright 2018 by Turkish Society of Obstetrics and Gynecology

Turkish Journal of Obstetrics and Gynecology published by Galenos Publishing House 
PRECIS: Diabetes in pregnancy study group of India criteria versus carpenter coustan criteria for diagnosing gestational diabetes mellitus.

\section{Introduction}

Gestational diabetes mellitus (GDM) is defined as any degree of glucose intolerance that is diagnosed for the first time during pregnancy, irrespective of treatment with diet or insulin ${ }^{(1,2)}$. GDM predisposes to future risk of type-2 DM in both the mother and her offspring ${ }^{(3)}$. Twenty to fifty percent of women with GDM will develop type-2 DM in the 5-10 years after delivery, corresponding to a 7.4-fold increased risk. Untreated GDM during pregnancy may lead to an increased risk of largefor-gestational-age births, low blood sugar, and jaundice in the neonatal period ${ }^{(4,5)}$. The prevalence of GDM is increasing worldwide proportionate to DM in the population. GDM occurs in up to $14 \%$ of all pregnancies in the United States of America (USA), whereas Asians have an 11.3 higher relativerisk of $\mathrm{GDM}^{(6)}$. Indian women with GDM have a higher risk of diabetes and metabolic syndrome ${ }^{(7)}$. Early detection of glucose intolerance during pregnancy has tri-pronged implications. One, GDM offers a timely opportunity for screening, management, and prevention of GDM and type-2 DM in pregnant women. Secondly, it prevents fetal complications thereby improving neonatal outcomes ${ }^{(8)}$. Thirdly, it offers the development, testing, and implementation of clinical and epidemiologic strategies for diabetes prevention in the population ${ }^{(9)}$. In the absence of consensus-based guidelines for the screening and diagnosis of GDM, there are variations in antenatal-care protocols ${ }^{(10)}$. There are variations between the American Diabetes Association (ADA) recommendations of selective screening vis-a-vis the American College of Obstetricians and Gynecologists (ACOG), which recommends universal screening. Universal mandatory screening for GDM is becoming the standard of antenatal-care even in low-income countries, notwithstanding healthcare equity and accessibility. Most institutions offer a 2-step procedure for screening and diagnosis of GDM as per the Carpenter Coustan criteria (CCC), which is cumbersome and entails additional costs to the exchequer. The international hyperglycemia and pregnancy outcome study results were promulgated by the International Association of Diabetes and Pregnancy Study Groups (IADPSG), which recommended a single-step testing methodology, reducing costs, and improving patient convenience. The IADPSG thresholds of fasting $>92 \mathrm{mg} /$ $\mathrm{dL}, 1$ hour $\geq 180 \mathrm{mg} / \mathrm{dL}$, or 2 hour $\geq 153 \mathrm{mg} / \mathrm{dL}$ plasma venous glucose values after a $75 \mathrm{~g}$ oral glucose tolerance test (OGTT) were accepted by the World Health Organization (WHO) and the ADA in 2013 and 2014, respectively, despite having been reported as having lower sensitivity ${ }^{(11-13)}$. The Diabetes in Pregnancy Study Group of India (DIPSI) criteria are a major breakthrough because they cater for the screening and diagnosis of all pregnant women irrespective of fasting state through a simple, economical, and convenient single-step procedure with a $75 \mathrm{~g} 2$ hour glucose test with a cut-off point of $>140 \mathrm{mg} / \mathrm{dL}$ for diagnosis. This prospective study was undertaken to validate the single-step non-fasting $75 \mathrm{~g}$ DIPSI criteria of GDM in Indian patients in comparison with the two-step fasting $100 \mathrm{~g}$ OGTT with the $\mathrm{CCC}^{(14)}$.

\section{Materials and Methods}

The prospective comparative triple-blind study was conducted with 200 pregnant women who presented to the antenatal clinic of a 1600-bed tertiary-care teaching hospital in Western India over a period of two years from May 2012 to April 2014, after obtaining written informed consents and approval from Armed forces Medical Coleges Ethics Committee. All pregnant women with recorded $\leq 20$ weeks period of gestation (POG) were included. Patients with a history of GDM/impaired glucose tolerance/DM, unexplained stillbirth, a macrosomic baby, congenital anomalies or birth injuries were excluded. Triple-blinding of patients, gynecologists, and pathologists was ensured to eliminate confounding and bias. All 200 patients were subjected to comparative testing through a non-fasting $75 \mathrm{~g}$ oral glucose (DIPSI) and fasting $100 \mathrm{~g}$ OGTT interpreted by CCC at less than 20 weeks POG and again between 24-28 weeks POG, with a temporal separation of $\leq 4$ days between the non-fasting OGTT with the DIPSI criteria and fasting OGTT with CCC. Plasma venous blood glucose levels were estimated using the hexokinase method on an autoanalyzer (Siemens Healthcare Diagnostics, Inc., West Sacramento, CA 95691 USA). Values $\geq 140 \mathrm{mg} / \mathrm{dL}$ at 2 hours were considered positive with the DIPSI criteria. Any two values from $\geq 95 \mathrm{mg} / \mathrm{dL}$ for fasting, $\geq 180 \mathrm{mg} / \mathrm{dL}$ at 1 hour, $\geq 155 \mathrm{mg} / \mathrm{dL}$ at 2 hours, and $\geq 140 \mathrm{mg} / \mathrm{dL}$ at 3 hours were considered positive with the $100 \mathrm{~g}$ OGTT with the CCC for the diagnosis of GDM. Quality control was ensured using internal quality control kits, Levey-Jennings charts based on lab-derived mean and standard deviation, corrective action on violations of Westgard rules, and subscribed external quality controls.

\section{Statistical Analysis}

Data were analyzed using SPSS (version 21; IBM Corporation). The patients' clinicodemographic profiles and blood glucose levels were correlated for descriptive statistics including frequency, percentages, and 95\% confidence intervals (CI).

\section{Results}

The study had a 100\% follow-up with no drop-outs. The mean age and body mass index (BMI) of the patients were $24.26 \pm 3.75$ years and $20.7 \pm 3.07 \mathrm{~kg} / \mathrm{m}^{2}$. Of the 200 women, $31 / 200(15.5 \%$, 95\% CI: 10.93-21.44) tested positive with the DIPSI criteria, and 26/200 (10.5\%, 95\% CI: 6.77-15.81) tested positive in the 100 gm OGTT as per the CCC. The 169 women who initially tested negative with the DIPSI criteria continued to be negative 
on repeat testing with the DIPSI and CCC at 24-28 weeks POG The prevalence of GDM in the study cohort was found as $15.5 \%$ using DIPSI criteria, and the prevalence of GDM after 100 gm OGTT with the CCC was 13\% (Table 1). The sensitivity, specificity, and positive and negative predictive values of the DIPSI guidelines were found as 100\%, 97.14\%, 83.87\%, and $100 \%$, respectively. The positive and negative likelihood ratios were 35.8 and zero. Diagnostic accuracy was found as $97.56 \%$ (Table 2).

\section{Discussion}

The effectiveness of glucose-challenge tests in the non-fasting state for screening and diagnosing GDM has long been a matter of debate. The ADA recommends only selective screening for

Table 1. Prevalence of gestational diabetes mellitus ( $n=200)$

$\begin{array}{llll}\text { GDM } & \begin{array}{lll}\text { Number of } \\ \text { patients }\end{array} & \begin{array}{l}\text { Percentage } \\ \text { (\%) }\end{array} & \text { intervals }\end{array}$

Non-fasting 75 gm Diabetes in Pregnancy Study Group criteria

\begin{tabular}{lccc} 
Present & 31 & 15.5 & $10.93-21.44 \%$ \\
\hline Absent & 169 & 84.5 & $78.56-89.07 \%$ \\
\hline Fasting & 100 gm OGTT & Carpenter & Coustan criteria \\
Present & 26 & 13 & $8.82-18.65 \%$ \\
Absent & 174 & 87 & $81.35-91.18 \%$ \\
\hline
\end{tabular}

OGTT: Oral glucose tolerance test, GDM: Gestational diabetes mellitus

Table 2. Evaluation of non-fasting 75 gm Diabetes in Pregnancy Study group criteria $(\mathrm{n}=200)$

\begin{tabular}{|c|c|c|c|}
\hline \multirow[t]{2}{*}{75 mg DIPSI } & \multicolumn{2}{|c|}{$\begin{array}{l}100 \text { mg OGTT } \\
\text { (Carpenter Coustan } \\
\text { criteria) }\end{array}$} & \multirow[t]{2}{*}{ Total } \\
\hline & Positive & Negative & \\
\hline Positive & 26 (a) & $5(b)$ & 31 \\
\hline Negative & $0(c)$ & $169(d)$ & 169 \\
\hline Total & 26 & 174 & 200 \\
\hline \multicolumn{3}{|c|}{ Diagnostic indicators } & $95 \% \mathrm{CI}$ \\
\hline \multicolumn{2}{|l|}{ Sensitivity } & $100 \%$ & $83.98-100 \%$ \\
\hline \multicolumn{2}{|l|}{ Specificity } & $97.21 \%$ & $93.06-98.93 \%$ \\
\hline \multicolumn{2}{|c|}{ Positive predictive value } & $83.87 \%$ & $65.53-93.9 \%$ \\
\hline \multicolumn{2}{|c|}{ Negative predictive value } & $100 \%$ & $97.23-100 \%$ \\
\hline \multicolumn{2}{|l|}{ Accuracy } & $97.56 \%$ & - \\
\hline \multicolumn{2}{|c|}{ Positive likelihood ratio } & 35.8 & $14.67-82.55 \%$ \\
\hline \multicolumn{2}{|c|}{ Negative likelihood ratio } & 0 & $2.29-11.77 \%$ \\
\hline \multicolumn{2}{|c|}{ Pre-test odds positive } & 0.14 & - \\
\hline \multicolumn{2}{|c|}{ Post-test odds positive } & 5.2 & - \\
\hline
\end{tabular}

GDM. Selective screening by risk factors such as woman's age, ethnicity, and BMI may miss some patients with GDM in the lower risk category, whereas more such patients may be diagnosed in the higher risk category. The reason for universal screening for GDM is to try and reduce the number of pregnant women undergoing OGTTs. A universal screening protocol requires the consideration of patient comfort, cost, and the risk of missing the diagnosis. The current ACOG recommendation of universal screening is a more practical approach but it advocates universal screening using two-step methods. Currently, the most used screening test is the oral glucose challenge test (OGCT) with 50 $\mathrm{g}$ of glucose followed by an OGTT with $100 \mathrm{~g}$ of glucose. Other screening tests and cut-off values are fasting blood glucose (126 $\mathrm{mg} / \mathrm{dL}, 7.0 \mathrm{mmol} / \mathrm{L})$ and random blood glucose $(200 \mathrm{mg} / \mathrm{dL}$, $11.1 \mathrm{mmol} / \mathrm{L}$ ). The diagnostic test for GDM has always been the $100 \mathrm{~g} 3$ hour OGTT. The WHO-IADPSG $75 \mathrm{~g}$ OGTT is currently recommended by the WHO for the diagnosis of GDM and it is widely used in Europe. The 100-gm OGTT is still predominantly used in the USA. However, in countries such as Saudi Arabia, Nigeria, and China, a 1 hour 50 g OGCT at 24-28 weeks of gestation is considered as a reliable universal screening test for GDM. Measurements of blood glucose levels in capillary bloods using a glucometer has made screening easy and simple because it can be performed in an office setting and does not require elaborate laboratory facilities, which may be far and few in resource-limited healthcare environments. It is important to know that capillary blood glucose levels are comparable to venous blood glucose levels during the fasting state but are higher after meals ${ }^{(15)}$. Most institutions offer a 2-step procedure for screening and diagnosis of GDM, under ADA, ACOG, WHO-IADPSG, Canadian Diabetes Association, National Diabetes Data Group (NDDG), National Institute of Health and Care Excellence in the United Kingdom and/or Australasian criteria. Reproducibility has been reported as 78\% at best. In the $4^{\text {th }}$ International Workshop Conference on GDM in 1997, a consensus was reached on replacing NDDG criteria with CCC criteria, which have lower threshold values for the diagnosis of $\mathrm{GDM}^{(16-18)}$. The screening and diagnosis of GDM has been simplified from the two-step fasting OGTT under ADA criteria/CCC to single-step fasting OGTT under WHO-IADPSG criteria. The 75 g DIPSI criteria with a 2 hour cut-off value of $\geq 140 \mathrm{mg} / \mathrm{dL}$ is a notch simpler than the WHO-IADPSG criteria because it offers both screening and diagnosis with a single-step non-fasting OGTT, which is immensely practical, economical, feasible, and convenient for patients and obstetric healthcare providers. The DIPSI criteria offer a promising technique with a high sensitivity of $100 \%$, specificity of $97.21 \%$, accuracy of $97.56 \%$, and negative predictive value of $100 \%$, compared with the fasting $100 \mathrm{~g}$ OGTT as per the CCC as seen in this study. Various studies have shown higher sensitivity and specificity of non-fasting $75 \mathrm{~g}$ two hour DIPSI testing compared with other criteria ${ }^{(19)}$. The DIPSI criteria have demonstrated $100 \%$ sensitivity, $100 \%$ specificity, and 94\% diagnostic accuracy ${ }^{(20-23)}$. 
Non-fasting OGTT causes the least disturbance to a pregnant woman's routine activities. Even if the DIPSI test is to be repeated in each trimester, the cost of performing DIPSI procedures will be less than the cost of performing any other diagnostic procedures because it requires little preparation, without requiring the prior interposition of the screening test. DIPSI has been proven to be a suitable test with higher sensitivity than WHO-IADPSG criteria in consonance with this study ${ }^{(24,25)}$. The DIPSI criteria have limitations in comparison with other OGTT criteria as seen in different patient populations, which may be a doubled-edged decision conundrum. The DIPSI criteria may not be able to account for fasting hyperglycemia. False-positive GDM with the DIPSI criteria in the absence of confirmatory GDM tested by other OGTT with low PPV, can lead to psychological stress, clinico-ultrasonographic surveillance, and interventions. False-negative GDM with DIPSI may be labeled as normal and may impact fetomaternal outcomes. DIPSI is based on the observations of the diabetes in pregnancy and awareness project. OGTT irrespective of last meal timing to diagnose GDM has been proven, which is in accordance to DIPSI guidelines. It is important to accept that no test is $100 \%$ sensitive or specific or has a 100\% PPV and NPV. The WHO-IADPSG criteria have been reported to have lower sensitivity. Certain studies reported a lower sensitivity of DIPSI in comparison with the $75 \mathrm{~g}$ OGTT; however, almost all of these studies also reported high specificity and negative predictive values of DIPSI ${ }^{(26-28)}$. The high negative predictive value with a $75 \mathrm{~g}$ non-fasting DIPSI can definitely rule out GDM, thus making DIPSI a convenient and costeffective screening tool for outpatients in antenatal centers ${ }^{(29-31)}$. However, the approach has limitations and cannot be concluded as superior to the universal approach with this study. Indian studies reported the prevalence of GDM as between 16.55\% and $22 \%$ using the DIPSI criteria, which is comparable to the prevalence of $15.5 \%$ in this study ${ }^{(32,33)}$. Challenges in laboratory quality control exist in developing countries conducting massscreening in resource limited facilities, which affects clinical decision- making(34). The DIPSI criteria have been included in the guidelines of the Ministry of Health and Family Welfare, Government of India( ${ }^{(35-37)}$.

\section{Study Limitations}

The study is limited by sample size and unaccounted fasting hyperglycemia.

\section{Conclusion}

The DIPSI criteria have high sensitivity, specificity, negative predictive values and diagnostic accuracy. DIPSI offers simplicity, feasibility, convenience, and repeatability, while economizing universal screening and diagnoses of GDM on a mass-scale. The DIPSI procedures have the potential to be applied to the entire obstetric population, in the implementation of public health programs to diagnose GDM in the community, thus reaching the needs of the developing world.

\section{Ethics}

Ethics Committee Approval: Approval of Institutional Armed Forces Medical College, Pune Ethics committee taken approval number: AFMC/2011-14/OBG/01.

Informed Consent: Written and informed consent was duly taken by all participants.

Peer-review: Externally peer-reviewed.

\section{Authorship Contributions}

Surgical and Medical Practices: S.K., Concept: S.K., H.B., Design: S.K., D.P., Data Collection or Processing: S.K., D.P., Analysis or Interpretation: S.K., H.B., I.D.K., Literature Search: S.K., H.B., I.D.K., Writing: S.K., I.D.K.

Conflict of Interest: No conflict of interest was declared by the authors.

Financial Disclosure: The authors declared that this study received no financial support.

\section{References}

1. Khan S, Khan ID. The Pregnant Indian Pilgrim At Hajj And Associated Obstetric And Neonatal Outcomes: A 3-Year Experience Of Indian Hajj Medical Mission. Sultan Qaboos Univ Med Journal Epub 2018

2. Khan S, Bal H, Khan ID, Paul D. Feto-Maternal Outcome In Women Diagnosed For Gestational Diabetes Mellitus in Western India: A two-year prospective study. Iranian Journal of Diabetes and Obesity Epub 2018

3. Dornhorst A, Rossi M. Risk and Prevention of Type 2 Diabetes in women with Gestational Diabetes. Diabetes Care 1998;21(Suppl 2):43-9

4. Jovanovic L, Pettit DJ. Gestational diabetes mellitus. JAMA 2001;286:2516-8

5. Bellamy L, Casas JP, Hingorani AD, Williams D. Type 2 diabetes mellitus after gestational diabetes: a systematic review and metaanalysis. Lancet 2009;373:1773-9.

6. Rosenblatt B. Prevalence, Health Behaviors, and Preventive Health Practices among Adult Coloradans with Diagnosed diabetes: Results from the Behavioral Risk Factor Surveillance System, 1997-2000. Denver, Colorado Department of Public Health; 2002.

7. Kale SD, Yajnik CS, Kulkarni SR, Meenakumari K, Joglekar AA, Khorsand N, et al. High risk of diabetes and metabolic syndrome in Indian women with gestational diabetes mellitus. Diabet Med 2004:21:1257-8

8. Khan S, Bal H, Paul D, Khan ID. Obstetric and Neonatal Outcomes In Women Diagnosed For Gestational Diabetes Mellitus. Journal of Archives in Military Medicine. 5(1): e44537, DOI: 10.5812/ jamm.44324.http://jammonline.com/?page=article\&article_ id $=44537$

9. Buchanan TA, Xiang A, Kjos SL, Watanabe R. What is Gestational diabetes? Diabetes Care 2007;30(Suppl 2):105-11.

10. Rani PR, Begum J. Screening and Diagnosis of Gestational Diabetes Mellitus, Where Do We Stand. J Clin Diagn Res 2016;10:1-4.

11. HAPO Study Cooperative Research Group, Metzger BE, Lowe LP, Dyer AR, Trimble ER, Chaovarindr U, et al. Hyperglycemia and adverse pregnancy outcomes. N Engl J Med 2008;358:1991-2002.

12. International Association of Diabetes and Pregnancy Study Groups Consensus Panel, Metzger BE, Gabbe SG, Persson B, Buchanan TA, Catalano PA, et al. International association of diabetes and pregnancy 
study groups recommendations on the diagnosis and classification of hyperglycemia in pregnancy. Diabetes Care 2010;33:676-82.

13. Geetha N, Sangeetha KG. Comparison of IADPSG And DIPSI Criteria for Diagnosis of Gestational Diabetes Mellitus. IOSR Journal of Dental and Medical Sciences 2016;15:1-4.

14. Seshiah V, Balaji V, Balaji MS. Scope for Prevention of Diabetes - Focus intrauterine milieu Interieur. J Assoc Physicians India 2008;56:10913.

15. Khan ID, Gupta N, Rangan NM, Singh R, Sharma AK, Khurana A, et al. Evaluation Of Pre and Post Analytical Variables in Clinical Microbiology Services in Multidisciplinary ICU of a Medical College And Tertiary Care Hospital. J Basic Clin Med 2016;5:2-4.

16. Hunt KJ, Schullar KL. The increasing prevalence of Diabetes in Pregnancy. Obstet Gynaecol Clin North Am 2007;34:173-99.

17. American College of Obstetricians and Gynecologists Committee on Practice Bulletins-Obstetrics. ACOG Practice Bulletin. Clinical management guidelines for obstetrician-gynecologists. Number 30, September 2001 (replaces Technical Bulletin Number 200, December 1994). Gestational diabetes. Obstet Gynecol 2001;98:525-38.

18. Polur H, Rrora R, Bandela PV. A Minireview on Diagnostic Criteria Of Gestational Diabetes Mellitus (GDM). J Pharm Sci Res 2015;7:53841.

19. Sharma K, Wahi P, Gupta A, Jandial K, Bhagat R, Gupta R, et al. Single glucose challenge test procedure for diagnosis of gestational diabetes mellitus: a Jammu cohort study. J Assoc Physicians India 2013;61:558-9.

20. Anjalakshi C, Balaji V, Balaji MS, Ashalata S, Suganthi S, Arthi T, et al. A single test procedure to diagnose gestational diabetes mellitus. Acta Diabetol 2009;46:51-4.

21. Junnnare KK, Adhau SR, Hegde MV, Naphade PR. Screening of gestational diabetes mellitus in antenatal women using DIPSI guidelines. International Journal of Research in Medical Science. 2016;4:446-9.

22. Polur H, Prasad KD, Bandela PV, Hindumathi, Saheb SH. Diabetes in Pregnancy Study Group in India (DIPSI) - A Novel Criterion to Diagnose GDM. IJBcRR 2016;10:1-6.

23. Mahalakshmi MM, Bhavadharini B, Maheshwari K, Anjana RM, Jebarani S, Ninov L, et al. Current practices in the diagnosis and management of gestational diabetes mellitus in India (WINGS-5). Indian J Endocrinol Metab 2016;20:364-8.

24. Magon N, Chauhan M. Diagnosing GDM: Role of simple, cost effective, and sensitive DIPSI test. J Obstet Gynaecol India 2014;64:299-300.

25. Mohan V, Usha S, Uma R. Screening for gestational diabetes in India: Where do we stand? J Postgrad Med 2015;61:151-4.

26. Mohan V, Mahalakshmi MM, Bhavadharini B, Maheswari K, Kalaiyarasi G, Anjana RM, et al. Comparison of screening for gestational diabetes mellitus by oral glucose tolerance tests done in the non-fasting (random) and fasting states. Acta Diabetol 2014;51:1007-13.

27. Vij P, Jha S, Gupta SK, Aneja A, Mathur R, Waghdhare S, et al. Comparison of DIPSI and IADPSG criteria for diagnosis of GDM: A study in a North Indian tertiary care center. Int J Diabetes Dev Ctries 2015;35:285-8

28. Herath M, Weerarathna TP, Umesha D. Is non fasting glucose challenge test sensitive enough to diagnose gestational diabetes mellitus? Int Arch Med 2015;8:1-8.

29. Beischer NA, Oats JN, Henry OA, Sheedy MT, Walstab JE. Incidence and severity of gestational diabetes mellitus according to country of birth in women living in Australia. Diabetes 1991;40(Suppl 2):35-8.

30. International Association of Diabetes and Pregnancy Study Groups Consensus Panel, Metzger BE, Gabbe SG, Persson B, Buchanan TA, Catalano PA, et al. International association of diabetes and pregnancy study groups recommendations on the diagnosis and classification of hyperglycemia in pregnancy. Diabetes Care 2010;33:676-82.

31. Tripathi R, Verma D, Gupta VK, Tyagi S, Kalaivani M3, Ramji S, et al. Evaluation of $75 \mathrm{~g}$ glucose load in non-fasting state [Diabetes in Pregnancy Study group of India (DIPSI) criteria] as a diagnostic test for gestational diabetes mellitus. Ind J Med Res 2017;145:209-14.

32. Seshiah V; Diabetes in Pregnancy Study Group. Fifth National Conference of Diabetes in Pregnancy Study Group, India. J Assoc Physicians India 2010;58:329-30.

33. Zargar AH, Sheikh MI, Bashir MI, Masoodi SR, Laway BA, Wani AI, et al. Prevalence of gestational diabetes mellitus in Kashmiri women from the Indian subcontinent. Diabetes Res Clin Pract 2004;66:13945.

34. Khan ID, Khan SA, Asima B, Hussaini SB, Zakiuddin M, Faisal FA. Morbidity and Mortality amongst Indian Hajj pilgrims: A 3-year experience of Indian Hajj Medical Mission in Mass-Gathering Medicine. J Infect Public Health 2018;11:165-70.

35. Seshiah V, Sahay BK, Das AK, Shah S, Banerjee S, Rao PV, et al. Gestational diabetes mellitus--Indian guidelines. J Indian Med Assoc 2009;107:799-802.

36. Anjalakshi C, Balaji V, Balaji MS, Ashalata S, Suganthi S, Arthi T, et al. A single test procedure to diagnose gestational diabetes mellitus. Acta Diabetol 2009;46:51-4.

37. National guidelines for diagnosis and management of gestational diabetes mellitus. New Delhi. Maternal Health Division, Ministry of Health \& Family Welfare. New Delhi: Government of India; 2015. 